\title{
Study of durability of fibrous cement based materials exposed to microorganisms
}

\author{
Vlasta Ondrejka Harbulakova ${ }^{\mathrm{a}}$, Adriana Estokova ${ }^{\mathrm{b}}$, Alena Luptakova ${ }^{\mathrm{c}}$, Simona Korenova ${ }^{\mathrm{b}}$ \\ ${ }^{a}$ Technical University of Kosice, Faculty of Civil Engineering, Institute of Environmental Engineering, Vysokoskolska 4,042000 Kosice, Slovakia \\ ${ }^{b}$ Technical University of Kosice, Faculty of Civil Engineering, Institute of Material Engineering, Vysokoskolska 4, 04200 Kosice, Slovakia \\ 'Slovak Academy of Science, Institute of Geotechnics, Watsonova 42, 04353 Kosice, Slovakia
}

\begin{abstract}
Fibrous cement based materials belong to the main long-lasting building materials. Few building materials offer a combination of architectural scope and strong technical specification as convincing as fibrous cement based materials e.g. cladding and roofing. One of the most desirable qualities of fibrous cement based board is its durability due to its ability to resist all kinds of weather conditions. Frost and thaw, heat, hale or rain does not pose a threat to fibrous cement based materials. Unlike wood siding, fibre board siding doesn't rot or require frequent repainting. Inside buildings fibrous cement based materials are applied as backer board in wet areas or for dry walls in heavy duty applications where fire resistance and strength are the dominant requirements.

The paper is primarily concerned with fibrous cement based specimens' microbially influenced under laboratory conditions during 3 months. In the experiment, sulphate-reducing bacteria (SRB) genera Desulfovibrio spp. and sulphur-oxidising bacteria Acidithiobacillus thiooxidans were used. The role of bacteria mentioned above has been linked to the generation of biogenic sulphuric acid resulting in corrosion process by dissolution of calcium containing minerals from the matrices of building materials.

Cement fibres boards exposed to simultaneous deleterious effect of bacteria were evaluated by weight and surface changes of the specimens and $\mathrm{pH}$ values changes in leachates.
\end{abstract}

Keywords: fibre-cement; composites; sulphur-oxidising bacteria; sulphate-reducing bacteria.

\section{Introduction}

Cement bonded wood has been investigated for more the one hundred years, whereas the industrial utilization of cement bonded particleboard started in the 1930's. However, most of the innovations have been done in the last 40 years. In the beginning cement bonded composites, particularly low-density boards, were mainly used for insulating purposes. In 1973, a Swiss company called Durisol was among the first manufacturers that produced a building panel consisting of small wood particles bonded in a cement matrix [1]. Wood-cement board, fibre-cement boards, gypsum fibreboards, and gypsum particleboards are now manufactured in various parts of the world. The opportunity for this industry to expand is substantial, because the raw material is available locally in many nations and, worldwide, the need for durable building products is strong [2]. Fiber cement composite products can be made use of in exterior and interior of a building such as siding, roofing, external cladding, internal lining, floors, walls, building boards, bricks, bracing, fencing and decorative elements. Fiber cement is also used in construction works such as dam, bridge deck, road building, sidewalk, flagstone paving, and so on. One of the main ingredients of fiber cement products is cellulose fibre from wood or non-wood sources, which are added to reinforce the cement composite. Also, small amounts of chemical additives are utilized to help the process, or provide products with particular characteristics [3]. Depending on their application, fibre-cement materials can offer a variety of advantages over traditional construction materials:

- as compared to wood, fibre-cement products offer improved dimensional stability, moisture resistance, decay resistance, and fire resistance;

- as compared to masonry, fibre-cement products enable faster, lower cost, lightweight construction;

- as compared to cement-based materials without fibres, fibre-cement products may offer improved toughness, ductility, and flexural capacity, as well as crack resistance and "nailability".

Corresponding author: Vlasta Ondrejka Harbulakova. E-mail address: vlasta.harbulakova@tuke.sk

http://dx.doi.org/10.3846/enviro.2014.024

(C) 2014 The Authors. Published by VGTU Press. This is an open-access article distributed under the terms of the Creative Commons Attribution License, which permits unrestricted use, distribution, and reproduction in any medium, provided the original author and source are credited. 
Fibre-cement composite products for residential housing have been generally limited to exterior applications, such as siding, and roofing. Their exterior use has been limited in the industry due to degradation to ambient wetting and drying. Thus, these components must be currently maintained by painting to avoid moisture problems. Furthermore, the applications of these composite products are non-structural (i.e., non-load-bearing) in nature [4]. Durability, toughness, high dimensional stability, resistance against environmental influences such as biodergradation of weatering but also availability of the raw material as well as economic factors are features which can make fibre-cement composites superior to conventionally bonded composites [5]. Their primary disadvangates is their vulnerability to decomposition in the alkaline environment present in Portland cement [6-7].

Changes in the fibre and fibre/cement interfacial region due to environmental interactions can affect the long-term performance of cement-based composites reinforced with natural fibres. Scanning electron microscopy by Mohr et al. [8] revealed ductile fibre behaviour, i.e., fibre pull-out and Poisson's effect at fibre tips, for those composite samples subjected to a low number of wet/dry cycles, even though the composites exhibited significant mechanical property losses.

However, the mechanism for this early increased fibre-cement bonding is unknown. One possible explanation for this behavior is the formation of calcium hydroxide or ettringite acting to density the transition zone around the fibres. Calcium hydroxide is soluble product of cement hydration that may reprecipitate in voids (i.e., fibre-cement interface) during wet/dry cycling. Ettringite may also form through a similar process known as delayed ettringite formation (DEF) [4].

Analyzing cement bonded particleboards by means of X-ray diffractometry, diffusion of cement molecules, especially calcium, magnesium and silicon, into the cell wall of wood particles was observed [9]. The alkaline environment arises during cement hydratation, where calcium hydroxide is produced; the result is an alkaline $(\mathrm{pH}=12.5)$ cement paste. Since hemicelluloses are noncrystaline and alkalinesoluble, they dissolve in the cement paste and affect cement crystallization [10]. Additionally, the acid and alkaline components, which penetrate into the wood, will damage the wooden structure, which results in extra loss of strength. Furthermore the degradation products, which are developed by the penetration of acid and alkaline components, will influence hydratation of cement [11].

Utilization of natural fibres is the subject of several studies, e.g. Pehanich et al. [12], Bruijn [13], d'Almeida et al. [14], Ouajai, Shanks [15], Kidalova et. al. [16], Kidalova et. al. [17].

The aim of the paper is to study the influence of simultaneous effect of Acidithiobacillus thiooxidans and Desulfovibrio bacteria to fibrous cement based boards and testing of selected physical and physico-chemical properties.

\section{Material and Methods}

\subsection{Fibre cement boards}

Two types of fibre cement boards ("O" and "G") commonly used were studied in laboratory experiments. The composition of tested fibre cement boards given by producer is in the Table 1.

Table 1. Composition of fibre-cement boards

\begin{tabular}{lll}
\hline \multirow{2}{*}{ Component (\%) } & \multicolumn{2}{l}{ Sample } \\
\cline { 2 - 3 } & $\mathrm{O}$ & $\mathrm{G}$ \\
\hline Portland cement & $40-80$ & $40-80$ \\
Cellulosic fibres & $4-15$ & $4-15$ \\
Limestone & $10-50$ & $10-50$ \\
Polyvinyl alcohol fibres & $0-2$ & $0-2$ \\
Coloring - iron oxides & up to 10 & - \\
Coloring - chromium & $0-5$ & $0-5$ \\
oxides & & up to 5 \\
Coloring - cobalt oxides & - & $0-3$ \\
Acrylic paint & $0-3$ & \\
\hline
\end{tabular}

The prepared boards' specimens of size $100 \times 150 \times 8 \mathrm{~mm}$ were treated during 2 hours in distilled water and then dried in aseptic box. Chemical sterilization of samples has been carried by treating the specimens in ethanol for 12 hours and by following drying in aseptic box during 2 hours. Thermal sterilization of samples has been carried at $80{ }^{\circ} \mathrm{C}$ during 3 hours.

\subsection{Bacteria}

Prepared fibre cement boards were exposed to simultaneous effect of sulphate-reducing and sulphur-oxidising bacteria. Acidithiobacillus thiooxidans (A.t.) representing sulphur-oxidising bacteria were isolated from the mixed culture obtained from the mine water (the shaft Pech, the locality Smolník, Eastern Slovakia). Cultivation of bacteria proceeded at optimal growth temperature of $28-30^{\circ} \mathrm{C}$ and $\mathrm{pH}$ of 4.0 by using the selective nutrient medium by Waksman and Joffe (Table 2 ). 
Table 2. Selective nutrient medium for Acidithiobacillus thiooxidans cultivation

\begin{tabular}{ll}
\hline Component & Concentration $(\mathrm{g} / \mathrm{L})$ \\
\hline $\mathrm{CaCl}_{2} \cdot 6 \mathrm{H}_{2} \mathrm{O}$ & 0.25 \\
$\left(\mathrm{NH}_{4}\right)_{2} \mathrm{SO}_{4}$ & 0.2 \\
$\mathrm{~K}_{2} \mathrm{HPO}_{4}$ & 3.0 \\
$\mathrm{MgSO}_{4} \cdot 7 \mathrm{H}_{2} \mathrm{O}$ & 0.5 \\
$\mathrm{FeSO}_{4} .7 \mathrm{H}_{2} \mathrm{O}$ & trace \\
$\mathrm{S}^{\circ}$ & 10.0 \\
Distilled water & added to $1000 \mathrm{~mL}$ \\
\hline
\end{tabular}

Desulfovibrio desulfuricans (D.d.) representing sulphate-reducing bacteria were isolated from a mixed culture obtained from the potable mineral water (Gajdovka spring, the locality Kosice-north, Slovakia). The selective nutrient medium by Postgate (Table 3) was used for isolation and cultivation of bacteria by ensuring the optimal growth conditions of $\mathrm{pH}$ ranging from 6.5 to 7.3 and temperature of $30^{\circ} \mathrm{C}$.

Table 3. Selective nutrient medium for Desulfovibrio desulfuricans cultivation

\begin{tabular}{llll}
\hline Component & Amount $(\mathrm{g})$ & Component & Amount $(\mathrm{g})$ \\
\hline Solution $A$ & & Solution $B$ & \\
$\mathrm{~K}_{2} \mathrm{HPO}_{4}$ & 0.5 & $\mathrm{FeSO}_{4} \cdot 7 \mathrm{H}_{2} \mathrm{O}$ & 0.5 \\
$\mathrm{NH}_{4} \mathrm{Cl}$ & 1.0 & $10 \mathrm{M} \mathrm{H}_{2} \mathrm{SO}_{4}$ & drops \\
$\mathrm{Na}_{2} \mathrm{SO}_{4}$ & 1.0 & Distilled water & $10 \mathrm{~mL}$ \\
$\mathrm{CaCl}_{2} \cdot 2 \mathrm{H}_{2} \mathrm{O}$ & 0.1 & & \\
$\mathrm{MgSO}_{4} \cdot 7 \mathrm{H}_{2} \mathrm{O}$ & 2.0 & Solution $C$ & \\
$\mathrm{C}_{3} \mathrm{H}_{5} \mathrm{O}_{3} \mathrm{Na}$ & 2.0 & $\mathrm{C}_{2} \mathrm{H}_{3} \mathrm{O}_{2} \mathrm{SNa}$ & 0.1 \\
yeast extract & 1.0 & $\mathrm{C}_{6} \mathrm{H}_{8} \mathrm{O}_{6}$ & 0.1 \\
$\mathrm{C}_{12} \mathrm{H}_{6} \mathrm{NO} \mathrm{Na}_{4} \mathrm{Na}$ & 1.0 & Distilled water & $10 \mathrm{~mL}$ \\
Distilled water & $980 \mathrm{~mL}$ & & \\
\hline
\end{tabular}

\subsection{Laboratory experiment}

Simultaneous effect of bacteria influence mentioned above to cement boards has been studied under static laboratory conditions in glass containers (Fig. 1). The containers were filled by glass balls and bacteria Desulfovibrio desulfuricans on the bottom and covered by cotton-wool. One fibre-cement board was placed into one container on the cotton-wool surface. Acidithiobacillus thiooxidans bacteria were inoculated on the top of the fibre-cement sample. The inoculation of both bacteria species proceeded once a 7-day interval during 80 days. The exposition of fibre-cement boards to simultaneous effect of bacteria proceeded at temperature of $30^{\circ} \mathrm{C}$. The abiotic control experiments without bacteria were carried out the same way by addition the cultivation media only.

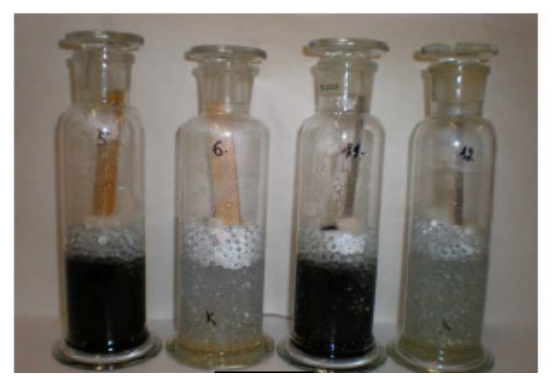

Fig. 1. Static laboratory experiments in glass containers

At the end experiment the fibre-cement boards were dried in aseptic box at laboratory temperature and consequently in laboratory drying equipment at $80^{\circ} \mathrm{C}$ and stored in excitatory. Exposed samples were investigated in terms of weight changes and surface deterioration.

The surface of studied fibre-cement boards were observed before and after the experiment by stereomicroscope equipped with OLYMPUS - Camedia C-770. 


\section{Results and Discussion}

The surface changes of fibre-cement samples were evaluated on the upper side, bottom side and cutting side as it shown in Figure 2.

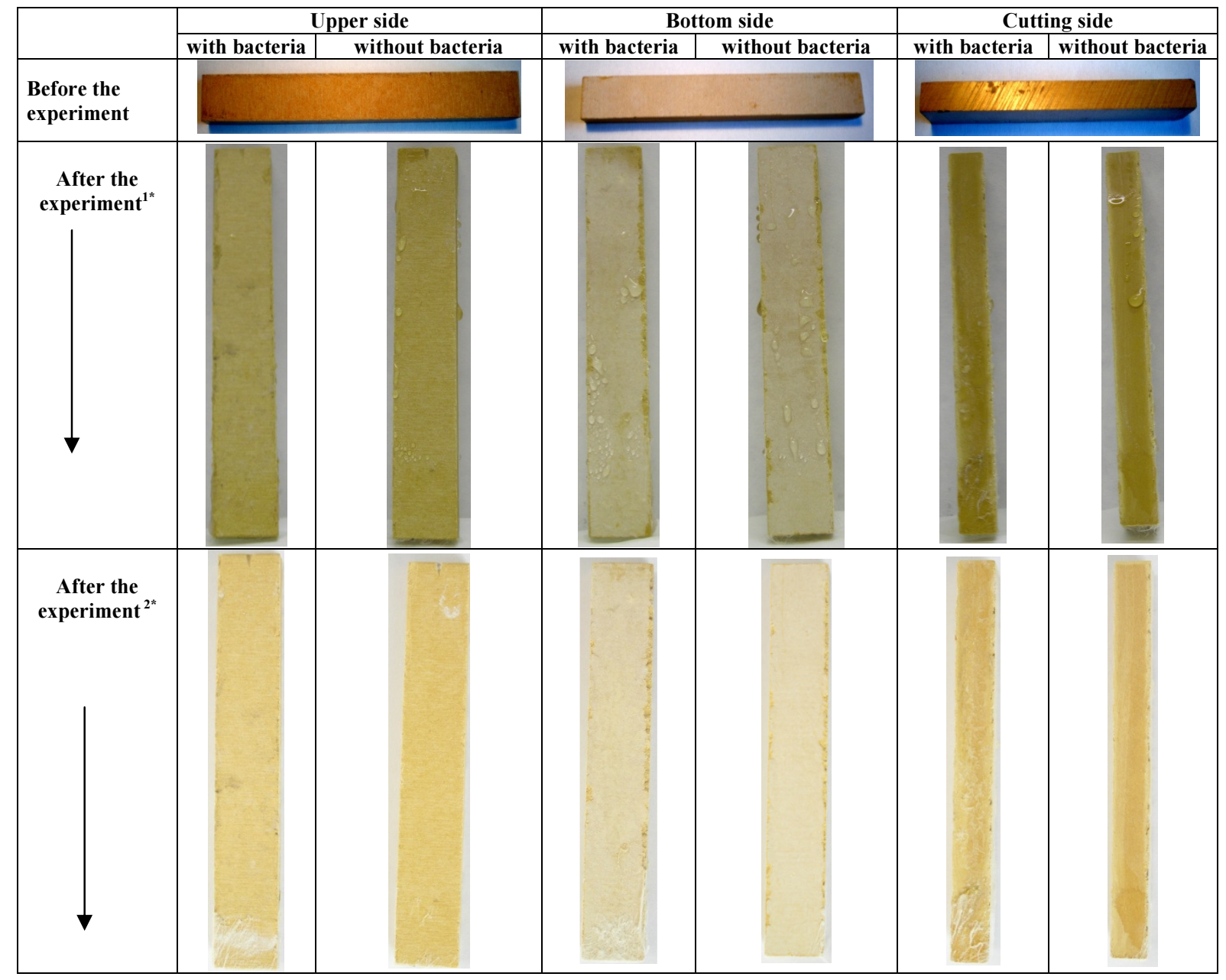

${ }^{1}$ - immediately after the end of experiment (still wet), ${ }^{2}$ - after drying, ${ }^{*}$ - direction of immersed part (composites were immersed in the bottom parts)

Fig. 2. Comparison of structure surface changes of type "O" fibre-cement composites with and without microorganisms influence

Figure 2 presents the comparison of the surface images for "O" type fibre-cement samples before and after the exposition to media with and without bacteria.

As it is seen in Figure 2 no significant visual changes were noticed. White stains in the bottom parts are the rests of the cotton wool in which the boars were placed. But, as it seen in detail in Figure 3, there was observed more significant rise of roughness of surface in case of samples exposed to bacteria when compared to samples exposed to environment without bacteria.

Visual changes in structure of board's surfaces of " $G$ " type composites are depicted in Figure 4. Visual changes were clearly visible for these samples on the side where the surface treatment was not done. Same as in case of composites "O" white stains in the bottom parts are the rests of the cotton wool in which the boars were placed. Simultaneous effect of both kinds of bacteria leads to white coatings creation on the surface of the boards (Fig. 4).

Considerable changes in weight were observed after 80 days laboratory simulation of simultaneous effect of Desulfovibrio desulfuricans as sulphate-reducing bacteria (SRB) and Acidithiobacillus thiooxidans as sulphur oxidizing bacteria on cement bounded boards. The weight changes of concrete samples are presented in Table 4. 


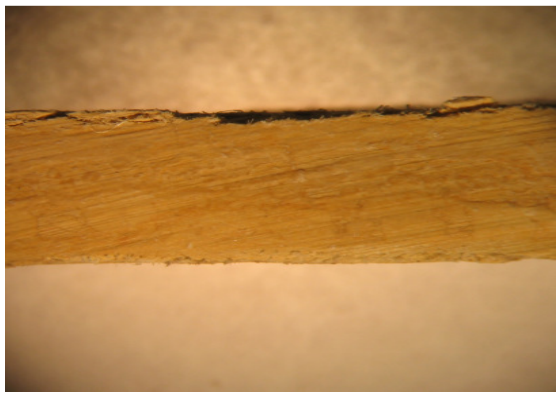

(a) Cutting side - under simultaneous effect of bacteria

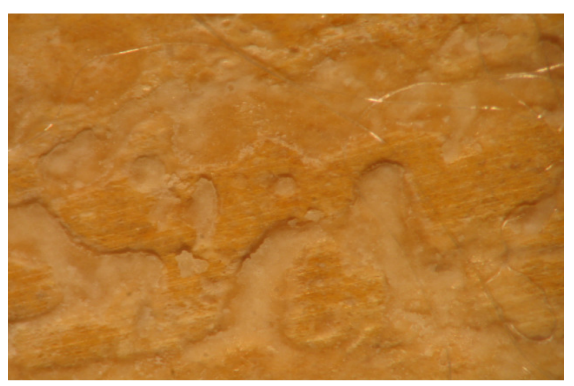

(b) Bottom side - under simultaneous effect of bacteria

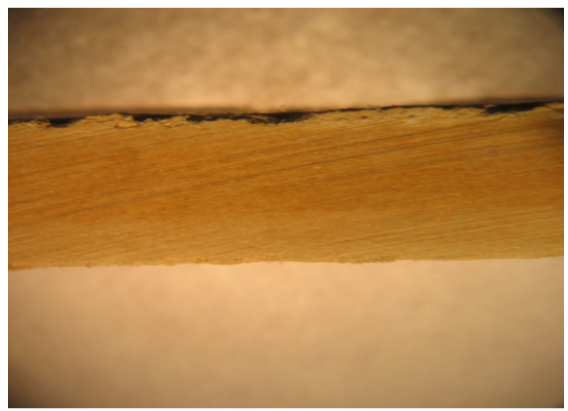

(c) Cutting side - abiotic control

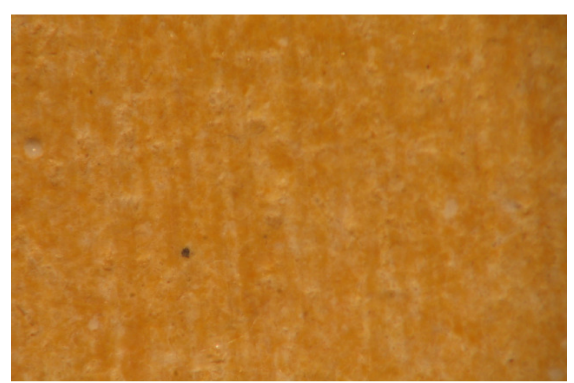

(d) Bottom side - abiotic control

Fig. 3. Comparison of surface changes of "O" type fibre - cement composites after experiment (mineralogical microscopy, magnification 20x0.7)

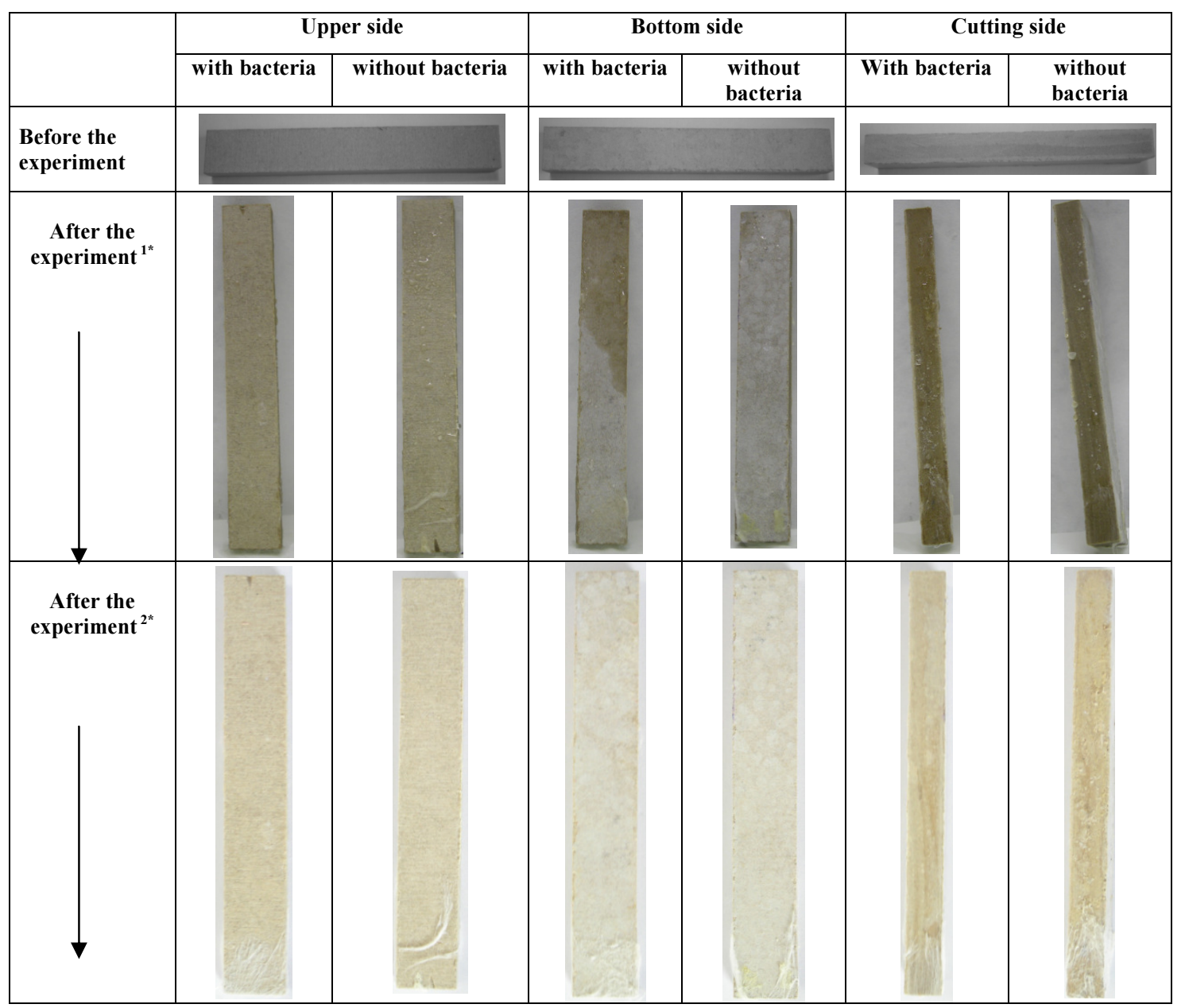

${ }^{1}$ - immediately after the end of experiment (still wet), ${ }^{2}$ - after drying, ${ }^{*}$ - direction of immersed part (composites were immersed in the bottom parts)

Fig. 4. Comparison of structure surface changes of " $G$ " type fibre-cement composites with and without microorganisms influence 


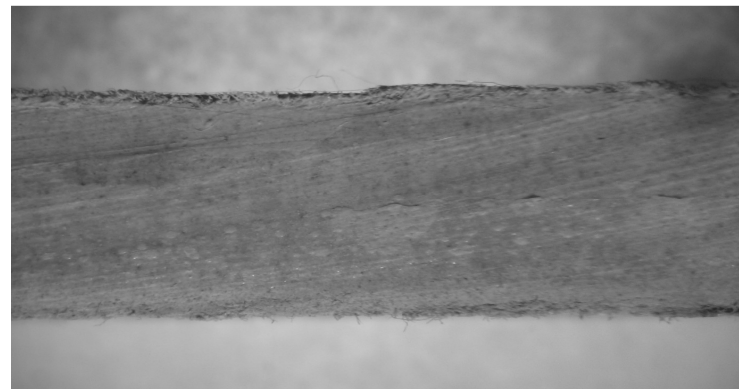

(a) Cutting side - under simultaneous effect of bacteria

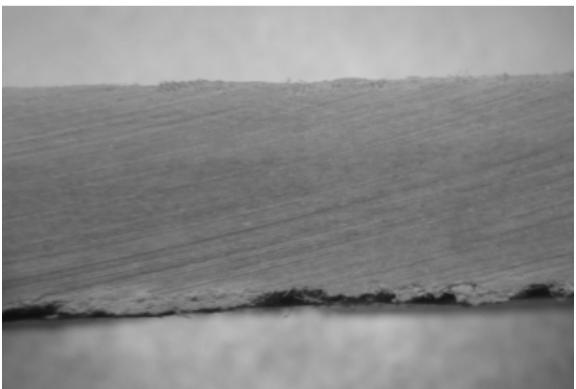

(b) Cutting side - abiotic control

Fig. 5. Comparison of surface changes of fibre - cement composites " $G$ ” (mineralogical microscopy, magnification 20x0.7)

The decrease in weight of 0.56 and $0.72 \%$ were observed for both investigated fibre-cements composites ("O" type) exposed to simultaneous effect of bacteria as well as exposed to environment without bacteria (Table 4). The increase in weight was measured for " $G$ " type composites with bacteria influence as well as for its abiotic control. These results corresponds to noticeable formation of solid phases on the composites surfaces as referred in [18-21] such as gypsum, ettringite or thaumasite.

Table 4. Weight changes of fibre-cement boards

\begin{tabular}{l|l|l|l|l}
\hline \multirow{2}{*}{ sample } & \multicolumn{2}{|l|}{ weight of sample [g] } & \multicolumn{2}{l}{ change of weight } \\
\cline { 2 - 5 } & before & after & {$[\mathrm{g}]$} & {$[\%]$} \\
\hline O & 18.5177 & 18.4142 & $\downarrow 0.1035$ & $\downarrow 0.56$ \\
Oc (abiotic control) & 18.3482 & 18.2169 & $\downarrow 0.1313$ & $\downarrow 0.72$ \\
G & 19.9533 & 20.2238 & $\uparrow 0.2705$ & $\uparrow 1.36$ \\
Gc (abiotic control) & 19.8126 & 20.0735 & $\uparrow 0.2609$ & $\uparrow 1.31$ \\
\hline
\end{tabular}

Deterioration of cement based materials under bacteria influence was confirmed by many researches [6, 22-25] but according to literature needs relatively long time. Partial research which proceeded during 80 days is probably too short for bacteria adaptation and demonstration the aggressive effect of them. In addition, the analysed fibre-cement boards don't represent the typical concrete materials.

\section{Conclusion}

Summarising the results of study of simultaneous effect of sulphur-oxidising and sulphate-reducing bacteria on fibre-cement boards, certain changes due to deterioration processes were manifested. Sulphuretum simulated under static conditions caused the increasing of surface roughness of tested samples exposed to simultaneous effect of Acidithiobacillus thiooxidans and Desulfovibrio desulfuricans. Much intensive deterioration of fibre-cement samples was noticed under influence of bacteria comparing to the environment without bacteria, as assumed. Thus the negative role of mentioned bacteria as deterioration factor was confirmed not only for typical cement based materials (e.g. concrete) but for fibrecement boards as well.

\section{Acknowledgements}

This work was financially supported by Slovak Grant Agency for Science within the Grant No. 2/0166/11 and 1/0481/13.

\section{References}

[1] Wolfe, R. W.; Gjinolli, A. 1996 Cement-bonded wood composites as and engineering material, The Use of Recycled Wood and Paper Building Applications, Madison, Wisconsine, 1996, 84-91.

[2] Moslemi, A. A. 1999. Emerging Technologies in mineral-bonded wood and fibre composites, Adv. Perform. Mater. 6: 161-179. http://dx.doi.org/10.1023/A:1008777812842

[3] Yatim, J. M.; Khalid, N. H. B. A.; Mahjoub, R. Paper seminar CIDB 2011. Available from internet: $\mathrm{http}: / /$ www.academia.edu/1266940/BIOCOMPOSITES_FOR_THE_CONSTRUCTION_MATERIALS_AND_STRUCTURES ; (last acces January 27, 2014)

[4] Mohr, B. J.; El-Ashkar, N. H.; Kurtis, K. E. 2004. Fiber-Cement Composites for Housing Construction: State-of-the-Art Review, in Proceedings of the NSF Housing Research Agenda Workshop, Orlando, USA, 2004. Florida.

[5] Frybort, S.; Mauritz, R.; Teischinger, A.; Müller, U. 2008. Cement bonded composites - a mechanical review, BioResources 3(2): $602-626$. 
[6] Velpari, V.; Ramachandran, B. E.; Bhaskaran, T. A.; Pai, B. C.; Balasubramanian, N. 1980. Alkaline resistance of fibres in cement, Journal of Materials Science 15(6): 1579-1584. http://dx.doi.org/10.1007/BF00752141

[7] Balaguru, P. N.; Shah, S. P. 1992. Fiber Reinforced Cement Composites, New York: McGraw Hill, 530.

[8] Mohr, B. J.; Nanko, H.; Kurtis, K. E. 2005. Durability of kraft pulp fiber-cement composites to wet/dry cycling, Cement \& Concrete Composite 27: 435-448. http://dx.doi.org/10.1016/j.cemconcomp.2004.07.006

[9] Parameswaran, N.; Brőker, F. W.; Simatupang, M. H. 1977. Zur Miktorechnologie mineralgebundener Holzwerkstoffe, Holzforschung 31: 173-178. (in German). http://dx.doi.org/10.1515/hfsg.1977.31.6.173

[10] Miller, D. P.; Moslemi, A. A. 1991. Wood-cement composites: Effect of model compounds on hydratation characteristics and tensile strength, Wood Fibre Sci. 23: 472-483

[11] Dewitz, K.; Kutschy, B.; Otto, T. 1984. Stofftransporte bei der Abbidung zementgebundener Holzwerkstoffe, Holztechnologieb 3: 151-154 (in German).

[12] Pehanich, J. L; Blankenhorn, P. R.; Silsbe, M. R. 2004. Wood fiber surface treatment level effects on selected mechanical properties of wood fibercement composites, Cement \& Concrete Research 34: 59-65. http://dx.doi.org/10.1016/S0008-8846(03)00193-5

[13] Bruijn, P. B. 2008. Hemp concretes, Paulien de Bruijn, Sweden: Alnarp.

[14] d' Almeida A., L. F. S.; Melo Filho, J. A.; Toledo Filho, R. D. 2009. Use of Curaua Fibers as Reinforcement in Cement Composites, Chemical Engineering Transactions 17: 1717-1722.

[15] Ouajai, S.; Shanks, R. A. 2009. Preparation, structure and mechanical properties of all-hemp cellulose biocomposites, Composites Science and Technology 69: 2119-2126. http://dx.doi.org/10.1016/j.compscitech.2009.05.005

[16] Kidalova, L.; Stevulova, N.; Terpakova, E.; Helcman, M. 2011. Effective Utilization of Alternative Materials in Lightweight Composites, Chemical Engineering Transactions 25: 1-6.

[17] Kidalova, L.; Stevulova, N.; Terpakova, E.; Sicakova, A. 2012. Utilization of alternative materials in lightweight composites, Journal of Cleaner Production 34(1): 116-119. http://dx.doi.org/10.1016/j.jclepro.2012.01.031

[18] Harbulakova, V.; Estokova, A.; Luptakova, A.; Stevulova, N.; Janak, G. 2009. Concrete specimens biodegradation by bacteria Acidithiobacillus thiooxidans and Desulfovibrio genera, Pollack Periodica 4(1): 83-92. http://dx.doi.org/10.1556/Pollack.4.2009.1.9

[19] Harbulakova, V.; Estokova, A.; Stevulova, N.; Luptakova, A.; Janak, G. 2009. Acid main drainage as the factor of microbial involved corrosion of concrete samples, in SGEM 2009. 2: 439-446. Sofia:Bulgaria.

[20] Ondrejka Harbulakova, V.; Estokova, A.; Stevulova, N.; Luptakova, A.; Foraiova, K. 2013. Current Trends in Investigation of Concrete Biodeterioration, Procedia Engineering: and Concrete Structures 2013 65: 346-351.

[21] Estokova, A.; Ondrejka Harbulakova, V.; Luptakova, A.; Stevulova, N., Study of the Deterioration of Concrete Influenced by Biogenic Sulphate Attack, Procedia Engineering:20th International Congress of Chemical and Process Engineering CHISA 2012 42: 1901-1908, Prague: Czech republic.

[22] O'Connell, M.; McNally, C.; Richardson, M.G., 2010. Biochemical attack on concrete in wastewater applications: A state of the art review, Cement \& Concrete Composites 32: 479-485. http://dx.doi.org/10.1016/j.cemconcomp.2010.05.001

[23] Mori, T.; Nonak,a, T.; Tazaki, K.; Koga; M., Hikosaka Y, Noda S. 1992. Interactions of nutrients, moisture and pH on microbial corrosion of concrete sewer pipes, Water Res 26(1): 29-37. http://dx.doi.org/10.1016/0043-1354(92)90107-F

[24] Hueck, H. J. 1968. The biodeterioration of materials - an appraisal Biodeterioration of Material, Eds. Walters, A.H. and Elphick, J.S. Elsevier, London, 6-12.

[25] Sand, W. 1997. Mirobial Mechanisms of Deterioration of Inorganic Substrates - A General Mechanistic Overview, Int. Biodet. Biodeg. 40(2-4):183190. http://dx.doi.org/10.1016/S0964-8305(97)00048-6 